\title{
НЕСОБСТВЕННО-ПРЯМАЯ РЕЧЬ КАК СРЕДСТВО СОЗДАНИЯ ИНДИВИДУАЛЬНОЙ КАРТИНЫ МИРА ДИСКУРСИВНОЙ ЛИЧНОСТИ ПЕРСОНАЖА И АВТОРА
}

\section{Нозлия Зариловна НОРМУРОДОВА}

Доктор филологических наук, доцент

Заведующий кафедрой межкультурной коммуникации и туризма

Ташкентский государственный университет узбекского языка и литературы имени Алишера Навои

Ташкент, Узбекистан

\section{НОХУСУСИЙ -ТЎҒРИ НУТҚ МУАЛЛИФ ВА ПЕРСОНАЖ ДИСКУРСИВ ШАХСИЯТИНИНГ ИНДИВИДУАЛ ДУНЁ МАНЗАРАСИНИ ШАКЛЛАНТИРУВЧИ ВОСИТА СИФАТИДА Нозлия Зариловна НОРМУРОДОВА \\ Филология фанлари доктори, доцент \\ “Маданиятлараро мулокот ва туризм" кафедраси мудири \\ Алишер Навоий номидаги Тошкент давлат ўзбек тили ва адабиёти университети Тошкент, Ўзбекистон}

\section{REPRESENTED SPEECH AS A MEANS OF CREATING AUTHOR'S AND PERSONAGE DISCOURSIVE PERSONALITIES' INDIVIDUAL WORLD PICTURE Nozliya Zarilovna NORMURODOVA \\ Doctor of Sciences, Associate Professor \\ The head of Intercultural Communication and Tourism Department \\ Tashkent State University of Uzbek Language and Literature named after Alisher Navoi Tashkent, Uzbekistan nozliyanormuodova1@gmail.com, nnormurodova@navoiy-uni.uz}

\section{UDC (УЎК, УДК): 811.111'42}

For citation (иқтибос келтириш учун, для цитирования):

Нормуродова Н. 3. Несобственно-прямая речь как средство создания индивидуальной картины мира дискурсивной личности персонажа и автора// Ўзбекистонда хорижий тиллар. - 2021. — № 1 (36). — C. 50-64. https://doi.org/10.36078/1618558210

Received: September 12, 2020 Accepted: December 17, 2020 Published: February 20, 2021

Copyright (C) 2021 by author(s) and Scientific Research Publishing Inc.
Аннотация. Антропоцентризм художественного дискурса отображается в дискурсивной личности автора и персонажа. Дискурсивная личность автора, проявляемая в авторской модальности и интенциональности, определяется всей системой языковых средств, используемых в художественном дискурсе, что отражается в отборе лексических средств, в семантической, прагматической и композиционной структуре дискурса. Вместе с тем очевидно, что некоторые фрагменты дискурса выражают дискурсивная личность автора и персонажа с наибольшей степенью, что позволяет рассматривать их в качестве вербальных маркеров антропоцентризма. Вербальными маркерами дискурсивной личности персонажа являются: а) художественный диалог; б) несобственно-прямая речь; в) графические средства, характеризуемые выражением авторской модальности и направленные на характеризацию образа персонажа в коммуникативно-прагматическом, когнитивном, культурном и психологическом аспектах. Несобственно-прямая речь (далее НПР), являясь сложным языковым явлением, основанным на взаимодействии речи автора и персонажа, способствует, с одной стороны, раскрытию концептуальной информации, с другой 
This work is licensed under the Creative Commons Attribution International License (CC BY 4.0). http://creativecommons.org/licenses/by/4.0/

\section{Open Access}

стороны, - выражению авторской модальности и интенциональности. Сущностной характеристикой НПР является её двуплановость, которая может быть представлена неравнозначно, т.е. в зависимости от прагматической установки на первый план может выходить дискурсивная личность (ДЛ) автора или персонажа. Другой характеристикой НПР является стилистическая маркированность и стилистическая гетерогенность, проявляемая в сентенции различных стилевых регистров, создающих контрастирование литературных и разговорных пластов, лексических и синтаксических единиц.

Ключевые слова: несобственно-прямая речь; художественный дискурс; концептуальная картина мира; антропоцентризм; стилистическая и символическая маркированность.

Аннотация. Бадиий дискурс антропоцентризми, аввало, муаллиф ва персонаж дискурсив шахсиятида акс этади. Муаллиф модаллиги ва интенционаллигида намоён бўлувчи муаллиф дискурсив шахсияти бадиий дискурсда ишлатиладиган тил воситаларининг бутун бир тизими билан аниқланади. Буни лексик воситаларнинг танланишида, дискурснинг семантик, прагматик ва композицион тузилишида кўриш мумкин. Шу билан бирга, дискурснинг айрим парчалари муаллиф ва персонаж дискурсив шахсиятини юқори даражада ойдинлаштиради. Бу эса уларга антропоцентризмнинг вербал маркерлари сифатида қараш имконини беради. Персонаж дискурсив шахсининг вербал маркерларига куйидагилар: а) бадиий диалог; б) нохусусий-тўғри нутқ; в) муаллиф модаллиги ифодаси билан характерланувчи ва персонаж образини коммуникативпрагматик, когнитив, маданий хамда психологик аспектларда характерлашга йўналтирилган график воситалар киради. Нохусусий-тўғри нутқ (кейинги ууринларда - НТН) муаллиф ва персонаж нутқининг ўзаро таъсирига асосланган мураккаб тил ходисаси бўлиб, бир томондан, концептуал ахборотни очиб беришга, иккинчи томондан эса муаллиф модаллиги ва интенционаллигини очиб беришга хизмат қилади. НТНнинг табиий характеристикаларидан бири икки планлилигидир. У турлича намоён бўлиши мумкин, яъни прагматик мақсадга кўра биринчи планга муаллиф ёки персонаж дискурсив шахсияти чиқарилиши мумкин. НТНнинг бошқа бир хусусияти стилистик маркерланганлик хамда турли услубий регистрлар сентенциясида намоён бўлувчи, адабий ва сўзлашув сатхлари (пластлари), лексик ва синтактик бирликлар ўртасида контрастликни юзага келтирувчи стилистик гетерогенликдир..

Калит сўзлари: нохусусий-тўғри нутқ; бадиий дискурс; оламнинг концептуал манзараси; антропоцентризм; стилистик ва рамзий белгилар.

Abstract. Anthropocentrism of literary discourse is primarily manifested in the discursive personality of the author and character. The author's discursive personality manifested in the author's modality and intentionality is determined by the entire system of language tools used in the literary discourse, which is reflected in the selection of lexical tools, in the semantic, pragmatic and compositional structure of the discourse. At the same time, some fragments of the discourse express the discursive personality of the author and the character with the greatest degree of obviousness, which allows us to consider them as verbal markers of anthropocentrism. The character's discursive personality is a complicated structure and includes the characteristics inherent in the discursive personality of the character and the author. The verbal markers of the character's discursive personality are a) 
literary discourse; b) represented speech; c) graphical means characterized by the expression of the author's modality and aimed at characterizing the character's image in communicatively pragmatic, cognitive, cultural, and psychological aspects. Represented speech, being a complex linguistic phenomenon based on the interaction of the speech of the author and the character, contributes, on the one hand, to the disclosure of conceptual information underlying in the literary discourse, and, on the other hand, to express author's modality and intentionality. The essential characteristic of the not pure direct speech is its double-sided nature, which can be presented unequally, i.e. depending on the pragmatic attitude, DL of the author or character may come to the fore. Another characteristic of not pure direct speech is its stylistic markedness and heterogeneity, presented in the convergence of stylistic techniques aimed at creating emotiveness and imagery.

Keywords: represented speech; literary discourse; conceptual world picture; antropthentrism; stylistic and symbolic markings.

Введение. Продолжая тему выражения ДЛ автора сквозь призму ДЛ персонажа, ещё раз подчеркнем, что ДЛ автора проявляется, прежде всего, в таких категориях, как авторская модальность и интенциональность. В этом плане еще одним языковым маркером ДЛ автора и персонажа является несобственно-прямая речь, также характеризуемая авторской модальностью и интенциональностью.

Способы передачи чужой (неавторской) речи и её разновидностей, в частности прямой речи, косвенной речи и несобственно-прямой речи, являются объектом исследования различных лингвистических дисциплин, таких как лингвистика текста, стилистика, грамматика, лингвопрагматика, семантика и др. В ряду способов передачи чужой речи особенную значимость для нашей работы представляет собой несобственно-прямая речь (НПР), которая выступает как одно из основных средств выражения дискурсивной личности автора и персонажа в художественном дискурсе благодаря своему свойству создания впечатления соприсутствия автора и персонажа.

1. В результате изучения научной литературы выявлено огромное многообразие способов определения НПР и выявления ее особенностей и признаков. В частности, НПР характеризуется «...как способ распространения иноязычной речи, объединяющий в себе признаки как прямой, так и косвенной речи» $(1,272)$. Лингвистические и синтаксические особенности чужого высказывания в некоторой степени проявляются в самой непрямой речи $(1 ; 2 ; 5,6,7,10)$, определенной обобщенной точке зрения, которая не относится ни к кому из персонажей. Отражая стилистические (лексические, интонационные и т. д.) черты чужой «речевой» манеры, прямую речь официально никак нельзя отличить от авторской, она и не отделена от нее «выдержками, тире или абзацами» (1), «специальная разновидность нарратива: разновидность вербального высказывания речи персонажа в эпическом произведении, согласно которой местоимения и формы глаголов отвечают авторскому сказанию, а лексика и синтаксис - самой речевой манере самого персонажа (8), «способ передачи чужой речи в виде непоследовательной непосредственной речи с позиции как самого героя, так и автора, позволяющий сберечь черты передаваемой речи» $(4,77)$. Отсюда 
становится ясно, что каждое определение ориентировано на определенную специфику НПР, в том числе на синтаксические и графические виды передаваемой речи персонажей. Вопреки разнообразным понятиям непрямой речи, в рамках нашего изучения необходимо отметить то, что НПР коррелирует речь автора и персонажа в пределах одного сюжетного отрывка. По нашему мнению, наиболее подробное объяснение НПР представлено в стилистическом словаре, в котором НПР трактуется как «метод распространения чужого высказывания, использующий детали прямой и косвенной речи». Это - речь рассказчика, в которой одновременно присутствуют лексика, смыслы (семантика), синтаксические построения речи героя первоисточника информации, его интонации, ощущения, размышления $(6,48)$.

Во многих исследованиях НПР рассматривается в качестве стилистического приёма $(6 ; 7 ; 5)$; единицы контекстновариативного членения наряду с такими единицами, как авторская речь (повествование, описание, рассуждение) и чужая речь (диалог, цитация) (И.Р. Гальперин, О.Н. Гришина, С.Н. Плотникова); текстовой интерференции, т. е. совмещение в НПР двух функций - «передачи текста персонажа и собственно повествования (которое осуществляется в тексте нарратора)» (4, 199).

Основная часть. В нашей работе НПР рассматривается как двуплановый стилистический приём, основанный на взаимодействии речи автора и персонажа, служащий, с одной стороны, выражению авторской модальности и интенциональности, a c другой стороны, - изображению психологического состояния персонажа, его мыслей, чувств и переживаний. Рассмотрим некоторые примеры с целью иллюстрации авторской интенциональности и модальности, выраженных в НПР из рассказа “Сup of Теа” Кетрин Менсфилд.

She was outside on the step, gazing at the winter afternoon. Rain was falling, and with the rain it seemed the dark came too, spinning down like ashes. There was a cold bitter taste in the air, and the newlighted lamps looked sad. Sad were the lights in the houses opposite. Dimly they burned as if regretting something. And people hurried by, hidden under their hateful umbrellas. Rosemary felt a strange pang. She pressed her muff against her breast; she wished she had the little box, too, to cling to. Of course the car was there. She'd only to cross the pavement. But still she waited. There are moments, horrible moments in life, when one emerges from shelter and looks out, and it's awful. One oughtn't to give way to them. One ought to go home and have an extra-special tea. But at the very instant of thinking that, a young girl, thin, dark, shadowy - where had she come from? - was standing at Rosemary's elbow and a voice like a sigh, almost like a sob, breathed: "Madam, may I speak to you a moment?"

"Speak to me?" Rosemary turned. She saw a little battered creature with enormous eyes, someone quite young, no older than herself, who clutched at her coat-collar with reddened hands, and shivered as though she had just come out of the water.

"M-madam, stammered the voice. Would you let me have the price of a cup of tea?" 
"A cup of tea?" There was something simple, sincere in that voice; it wasn't in the least the voice of a beggar. "Then have you no money at all?" asked Rosemary.

"None, madam," came the answer.

"How extraordinary!" Rosemary peered through the dusk and the girl gazed back at her. How more than extraordinary! And suddenly it seemed to Rosemary such an adventure. It was like something out of a novel by Dostoevsky, this meeting in the dusk. Supposing she took the girl home? Supposing she did do one of those things she was always reading about or seeing on the stage, what would happen? It would be thrilling. And she heard herself saying afterwards to the amazement of her friends: "I simply took her home with me," as she stepped forward and said to that dim person beside her: "Come home to tea with me" (A Cup of Tea, Mansfield).

Фактуальная информация - это случайная встреча двух девушек разного социального положения: великосветской дамы Розмари и Смит, девушки, просящей милостыню. Розмари в своем желании быть великодушной в глазах светского общества неожиданно приглашает девушку на чай к себе домой, но выгоняет её, когда муж обращает внимание на красоту бедной девушки.

Приведенный отрывок начинается с описания тоскливой унылой дождливой погоды (and with the rain it seemed the dark came too, spinning down like ashes). Далее следуют размышления персонажа (horrible moment of life, it's an awful). Внутренняя речь персонажа включает также авторскую речь, представленную портретным описанием бедной девушки (thin, dark, shadow a little battered creature with enormous eyes, someone quite young), которая сменяется произнесенной речью персонажа (where had' she come from). Далее следует диалог, включающий также внутреннюю речь персонажа, эмоциональное рассуждение героини о том, какой эффект она произведет на общество своим решением пригласить девушку на чай (extra ordinary adventure, thrilling, was like something out of a novel by Dostoevsky).

В данном примере ярко проявляется авторская интенциональность, направленная как на характеризацию личностных морально-нравственных качеств персонажа, так и его внутреннего психологического состояния. Розмари Фелл, богатая и молодая женщина, выходит из дорогого магазина на улицу, которая представляется ей чуждым и даже враждебным миром (hateful umbrellas, the dark came too, a cold bitter taste in the air, lamps looked sad). Розмари переживает чувство беспокойства и ужаса: Rosemary felt a strange pang... There are moments, horrible moments in life, when one emerges from shelter and looks out, and it's awful.

Примечательно и то, что наряду с авторской интенциональностью в этой внутренней речи персонажа проявляется и отрицательная авторская модальность - Розмари живёт в своей скорлупе и реальный мир её пугает.

Личностные моральные качества Розмари (бессердечность, лицемерие, расчёт и эгоизм) также эксплицируются в её речи посредством восклицательных и вопросительных предложений. Увидев бедную девушку, Розмари не думает о её состоянии, не испытывает к ней жалости. Вначале эта ситуация удивляет её 
(How extraordinary! How more than extraordinary!), а далее она представляет себя в окружении друзей, которым демонстрирует своё благородство, великодушие и щедрость, которые позволили ей взять простую, бедную, незнакомую девушку к себе домой. Вся эта ситуация для Розмари лишь приключение и повод показать себя.

Как показал анализ языкового материала, НПР также является одним из основных языковых средств выражения авторской модальности. Ярким примером этому служит рассказ “The Garden Party", который изобилует НПР, выражающей суждения автора, отражающие становление личности персонажа, его мысли и переживания.

Рассказ начинается с описания подготовки к вечеринке в саду семьи Шеридан. В саду работают рабочие, наблюдать за работой которых посылают Лауру, девушку лет шестнадцати. Лаура вначале испытывает смущение перед рабочими, пытается выглядеть взрослой и серьёзной. Однако в процессе наблюдения она понимает, что рабочим также свойственно чувство прекрасного. Рассмотрим следующие фрагменты:

His smile was so easy, so friendly, that Laura recovered. What nice eyes he had, small, but such a dark blue! And now she looked at the others, they were smiling too. "Cheer up, we won't bite," their smile seemed to say. How very nice workmen were! And what a beautiful morning!

Already the men had shouldered their staves and were making for the place. Only the tall fellow was left. He bent down, pinched a sprig of lavender, put his thumb and forefinger to his nose and snuffed up the smell. When Laura saw that gesture she forgot all about the karakas in her wonder at him caring for things like that - caring for the smell of lavender. How many men that she knew would have done such a thing? Oh, how extraordinarily nice workmen were, she thought. Why couldn't she have workmen for her friends rather than the silly boys she danced with and who came to Sunday night supper? She would get on much better with men like these.

Авторская модальность, отражающая его ценностные воззрения и суждения, в данных фрагментах НПР направлена, во-первых, на выражение симпатии к рабочим посредством описания их внешних характеристик (His smile was so easy, so friendly; What nice eyes he had, small, but such a dark blue!), а вовторых, на преодоление существующих в высшем обществе стереотипов, касающихся неотесанности, неучтивости, чёрствости, грубости и некультурности людей, занимающихся чёрной работой. Так, один из рабочих, несмотря на свою занятость, находит время, чтобы насладиться ароматом лаванды (He bent down, pinched a sprig of lavender, put his thumb and forefinger to his nose and snuffed up the smell). Это действие рабочего оказывает на Лауру большое впечатление, которое в НПР передаётся как авторской речью (When Laura saw that gesture she forgot all about the karakas in her wonder at him caring for things like that - caring for the smell of lavender), так и внутренней речью персонажа, отражающей, с одной стороны, эмоциональное состояние Лауры, испытывающей шок, удивление, изумление "несвойственным для рабочего" поведением (How many men that she knew would have done such a 
thing? Oh, how extraordinarily nice workmen were), a с другой стороны, процесс преломления её стереотипов, её мыслей и её мнения о рабочих (Why couldn't she have workmen for her friends rather than the silly boys she danced with and who came to Sunday night supper?). В итоге в конце НПР, внутренняя речь персонажа и авторская речь сливаются воедино (How very nice workmen were! She would get on much better with men like these), выражая положительную модальность и восхищение рабочими, способствуя таким образом изменению стереотипов главной героини рассказа.

Важно подчеркнуть двусторонность, имплицитность, семиотичность НПР. Двусторонний характер речевого процесса в НПР заключается в двунаправленности речи - автора и персонажа. В НПР происходит своеобразное взаимодействие двух семиотических пространств, диалог автора и героя в рамках общей речи/мысли. Погруженность речи автора и персонажа в пространство единой речи способствует выражению целого пласта чувств, переживаний, взглядов как автора, так и персонажа, создавая своеобразный диалог автора и персонажа, в который непосредственно вовлекается также и читатель. Данный процесс происходит имплицитно, так как НПР обычно вводится в текст без ссылок, без указаний на автора, что создаёт размытость границ между мыслями автора и героя. В НПР автор представляет текстовую информацию, которую читатель должен воспринять и правильно декодировать. Процесс декодирования информации читателем предусматривает нахождение языковой репрезентации дискурсивной личности автора и персонажа в НПР в процессе чтения и интерпретации и выявление имплицитной информации, которую хотел выразить автор, с опорой на стилистически маркированные смысловые центры НПР. Адекватная интерпретация НПР способствует выявлению, с одной стороны, авторской модальности и интенциональности, a с другой - смысловых, мыслительных, психологических импульсов персонажа, позволяя таким образом раскрытию концептуальной информации, заложенной в основу произведения.

Как уже было отмечено выше, одной из основных характеристик НПР является её двуплановость, основанная на взаимодействии речи автора и персонажа. Однако, как показал анализ практического материала, данная двуплановость не выражается в НПР в равной мере. В некоторых НПР в большей степени представлен план автора, а в других — план персонажа, что объясняется прагматической установкой НПР, направленной в большей степени на выражение дискурсивной личности автора или персонажа.

Так, в следующем примере ярко выражена дискурсивная личность персонажа:

It was cold in the street. There was a wind like ice. People went flitting by, very fast; the men walked like scissors; the women trod like cats. And nobody knew - nobody cared. Even if she broke down, if at last, after all these years, she were to cry, she'd find herself in the lock-up as like as not.

But at the thought of crying it was as though little Lennie leapt in his gran's arms. Ah, that's what she wants to do, my dove. Gran 
wants to cry. If she could only cry now, cry for a long time. Over everything, beginning with her first place and the cruel cook, going on to the doctor's, and then the seven little ones, death of her husband, the children's leaving her, and all the years of misery that led up to Lennie. But to have a proper cry over all these things would take a long time. All the same, the time for it had come. She must do it. She couldn't put it off any longer; she couldn't wait any more ... Where could she go?

"She's had a hard life, has Ma Parker." Yes, a hard life, indeed! Her chin began to tremble; there was no time to lose. But where? Where?

She couldn't go home; Ethel was there. It would frighten Ethel out of her life. She couldn't sit on a bench anywhere; people would come asking her questions. She couldn't possibly go back to the gentleman's flat; she had no right to cry in strangers' houses. If she sat on some steps a policeman would speak to her.

Oh, wasn't there anywhere where she could hide and keep herself to herself and stay as long as she liked, not disturbing anybody, and nobody worrying her? Wasn't there anywhere in the world where she could have her cry out - at last?

Ma Parker stood, looking up and down. The icy wind blew out her apron into a balloon. And now it began to rain. There was nowhere (Life of Ma Parker, Mansfield).

В рассказе повествуется о старой женщине - матушке Паркер, которая подрабатывает домработницей. Она приходит на работу на следующий день после похорон своего пятилетнего внука, единственной отдушины, которая у неё была. Мимолётный вопрос хозяина квартиры о том, как прошли похороны, навевает на неё воспоминания о своей жизни. Она приехала в Лондон ещё девушкой, несколько лет безвылазно работала на кухне, затем вышла замуж за пекаря, похоронила семерых детей и мужа, и в одиночку вырастила оставшихся шестерых детей, из которых с ней осталась только младшая дочь. Воспоминания тяжёлым бременем ложатся на матушку Паркер, которая впервые в жизни хочет выплакаться. Нахлынувшие на неё чувства становятся невыносимыми, и она выбегает на улицу, не зная, куда ей пойти, чтобы иметь возможность поплакать.

Вышеприведенный отрывок НПР отражает её психологическое состояние: a) невыносимое желание выплакаться: (Gran wants to cry. If she could only cry now, cry for a long time; She couldn't put it off any longer; she couldn't wait any more); б) осознание всей тяжести её жизни: (beginning with her first place and the cruel cook, going on to the doctor's, and then the seven little ones, death of her husband, the children's leaving her; "She's had a hard life, has Ma Parker." Yes, a hard life, indeed!); в) горечь от своей беспомощности (all the years of misery that led up to Lennie); г) тоска по внуку (But at the thought of crying it was as though little Lennie leapt in his gran's arms); д) осознание того, что ей некуда пойти (She couldn't go home; Ethel was there. It would frighten Ethel out of her life. She couldn't sit on a bench anywhere; people would come asking her questions. She couldn't possibly go back to the gentleman's flat; she had no right to cry in strangers' houses. If she sat on some steps a policeman would speak to her). 
Отличительной чертой таких НПР является использование ряда вопросительных предложений, которые в большинстве своем являются риторическими вопросами: Oh, wasn't there anywhere where she could hide and keep herself to herself and stay as long as she liked, not disturbing anybody, and nobody worrying her? Wasn't there anywhere in the world where she could have her cry out - at last?

Дискурсивная личность автора в вышеприведенном отрывке слабо выражена. Граница между авторской речью и речью персонажа настолько стирается, что часто трудно установить, когда говорит автор, а когда - персонаж. Примером этого могут служить следующие предложения: And nobody knew - nobody cared. Yes, a hard life, indeed! There was nowhere. Как известно, переключение речевых планов автора и персонажа в тексте может иметь грамматические, лексические, пунктуационные показатели. В вышеприведенном отрывке план автора ограничивается использованием личных и притяжательных местоимений (she, her), описанием состояния персонажа (Her chin began to tremble; Ma Parker stood, looking up and down); описанием погодных условий: (It was cold in the street; There was a wind like ice; And now it began to rain).

В следующем отрывке НПР на первый план выдвигается план автора, выражающий его отношение и оценку объектов и явлений окружающей действительности, способствуя таким образом выражению его дискурсивной личности. Например, в нижеследующем отрывке НПР преобладает авторское видение мира первой мировой войны:

So when the war broke out his whole instinct was against it: against war. He had not the faintest desire to overcome any foreigners or to help in their death. He had no conception of Imperial England, and Rule Britannia was just a joke to him. He was a pure-blooded Englishman, perfect in his race, and when he was truly himself he could no more have been aggressive on the score of his Englishness than a rose can be aggressive on the score of its rosiness.

No, he had no desire to defy Germany and to exalt England. The distinction between German and English was not for him the distinction between good and bad. It was the distinction between blue water-flowers and red or white bush-blossoms: just difference. The difference between the wild boar and the wild bear. And a man was good or bad according to his nature, not according to his nationality.

Egbert was well-bred, and this was part of his natural understanding. It was merely unnatural to him to hate a nation en bloc. Certain individuals he disliked, and others he liked, and the mass he knew nothing about. Certain deeds he disliked, certain deeds seemed natural to him, and about most deeds he had no particular feeling.

He had, however, the one deepest pure-bred instinct. He recoiled inevitably from having his feelings dictated to him by the mass feeling. His feelings were his own, his understanding was his own, and he would never go back on either, willingly. Shall a man become inferior to his own true knowledge and self, just because the mob expects it of him?

Герой рассказа размышляет о том, стоит ли ему идти на войну, против которой выступает всё его существо. Он 
чистокровный англичанин, аристократ, преданный традициям, любящий старину и считающий ниже своего достоинства ненавидеть тот или иной народ и нести ему смерть в угоду империалистической Британии. Дискурсивная личность автора и его видение мира представлены авторской речью посредством изображения мыслей Эгберта, поэтому грань между речью автора и персонажа стёрта. Автор как бы навязывает Эгберту свои идеи касательно: а) различий между народами, которые относятся к одной культуре (the distinction between blue waterflowers and red or white bush-blossoms: just difference. The difference between the wild boar and the wild bear); б) неестественности чувства агрессии (unnatural to him to hate a nation en bloc; he could no more have been aggressive on the score of his Englishness than a rose can be aggressive on the score of its rosiness); в) морально-личностных характеристиках, присущих человеку, а не всей нации (a man was good or bad according to his nature, not according to his nationality); г) свободы выбора, которая не должна зависеть от мнения большинства (He recoiled inevitably from having his feelings dictated to him by the mass feeling). Заканчивается НПР внутренней речью персонажа, выраженной риторическим вопросом, обращённым ко всему человечеству: "Shall a man become inferior to his own true knowledge and self, just because the mob expects it of him?". Несмотря на стёртость границ между речью автора и речью персонажа, в данном фрагменте НПР происходит переплетение голосов и мировидения автора и персонажа, представленное в большей степени в авторской речи. Вставка внутренней речи персонажа способствует сохранению синтаксических, композиционных и стилистических особенностей НПР.

Таким образом, двуплановость в НПР представляется неравнозначно. НПР с выраженным планом авторской речи в большей степени направлена на выражение дискурсивной личности автора, его мировоззрения, мировидения и оценки событий и явлений окружающего мира, в то время как НПР с выраженным планом речи персонажа нацелена на описание эмоционально-психологического состояния персонажа, его личных переживаний и чувств, мыслей и суждений, способствуя определению и выявлению дискурсивной личности персонажа.

В качестве следующей характеристики НПР можно отметить ее национально-культурную специфику. Являясь сложным языковым феноменом, НПР также является одним из основных средств выражения национально-культурных ценностей, особенностей национального мировоззрения и мировидения. Ярким примером этого является рассказ Д. Г. Лоуренса "England, my England”, в котором большое внимание уделяется проблеме национального английского характера. Рассказ изобилует НПР, способствующей выражению культурных ценностей и английского характера. Рассмотрим некоторые из них.

Как известно, неотъемлемой частью английской культуры, представляющей собой культурную ценность для британцев, являются концепты Дома и Сада. По мнению И.В. Арнольд, любовь и верность к природе и дому являются частью национального английского характера. Дом с камином и садом 
испокон веков символизировал семейный уют и стабильность английской семьи $(1,140)$. Именно поэтому во всех городах Англии располагаются огромные сады для прогулок и пикников, каждый британец, несмотря на размер придомового участка, старается создать сад с декоративными цветами и деревьями. В связи с вышесказанным рассмотрим следующие примеры:

The sunlight blazed down upon the earth, there was a vividness of flamy vegetation, of fierce seclusion amid the savage peace of the commons. Strange how the savage England lingers in patches: as here, amid these shaggy gorse commons, and marshy, snake infested places near the foot of the south downs. The spirit of place lingering on primeval, as when the Saxons came, so long ago.

Ah, how he had loved it! The green garden path, the tufts of flowers, purple and white columbines, and great oriental red poppies with their black chaps and mulleins tall and yellow, this flamy garden which had been a garden for a thousand years, scooped out in the little hollow among the snake-infested commons. He had made it flame with flowers, in a sun cup under its hedges and trees. So old, so old a place! And yet he had re-created it.

The timbered cottage with its sloping, cloak-like roof was old and forgotten. It belonged to the old England of hamlets and yeomen. Lost all alone on the edge of the common, at the end of a wide, grassy, briar-entangled lane shaded with oak, it had never known the world of today. Not till Egbert came with his bride. And he had come to fill it with flowers.

The house was ancient and very uncomfortable. But he did not want to alter it. Ah, marvellous to sit there in the wide, black, timeold chimney, at night when the wind roared overhead, and the wood which he had chopped himself sputtered on the hearth! Himself on one side the angle, and Winifred on the other.

Главный герой Эгберт созерцает сад, расположенный в пригородной усадьбе, который подарил молодожёнам тесть. Он гордится тем, что смог его снова восстановить (And yet he had recreated it; He had made it flame with flowers, in a sun cup under its hedges and trees). Будучи из аристократического рода, ценителем прекрасного и любителем природы, он восхищается обилием растительности, разнообразных красок (Ah, how he had loved it! The green garden path, the tufts of flowers, purple and white columbines, and great oriental red poppies with their black chaps and mulleins tall and yellow...). Особые чувства у него вызывает старинный дом с камином, который символизирует для Эгберта семейный уют (Ah, marvellous to sit there in the wide, black, timeold chimney... Himself on one side the angle, and Winifred on the other.).

Дискурсивная личность как автора, так и персонажа в НПР проявляется в выражении восхищения старым домом и садом, являющимися символами старой доброй Англии, веками сохранявшей свои традиции (So old, so old a place!; belonged to the old England of hamlets and yeomen; this flamy garden which had been a garden for a thousand years) и стойкость английского духа (Strange how the savage England lingers in patches). Одновременно с этим в НПР выражается тоска по уходящим в небытие английским национальным ценностям (The spirit of place lingering on primeval, as when the Saxons came, so long ago). 
Таким образом, вышеприведенный отрывок ярко иллюстрирует роль НПР в выражении аксиологических ценностей определенной лингвокультуры. Авторская модальность в данном случае проявляется в выражении чувств сожаления и переживания по поводу крушения и трансформации исконно английских ценностей.

Одним из ведущих признаков НПР как стилистического приема является стилистическая маркированность, которая, как показал анализ языкового материала, в основном представлена конвергенцией стилистических приёмов, способствующих выражению эмоционального состояния персонажа, становясь одним из основных сигналов эмотивности и создания образности.

Проиллюстрируем сказанное следующими примерами из текста:

Miss Brill put up her hand and touched her fur. Dear little thing! It was nice to feel it again. She had taken it out of its box that afternoon, shaken out the moth powder, given it a good brush, and rubbed the life back into the dim little eyes. "What has been happening to me?" said the sad little eyes. Oh, how sweet it was to see them snap at her again from the red eiderdown! . . . But the nose, which was of some black composition, wasn't at all firm. It must have had a knock, somehow. Never mind - a little dab of black sealing-wax when the time came - when it was absolutely necessary . . . Little rogue! Yes, she really felt like that about it. Little rogue biting its tail just by her left ear. She could have taken it off and laid it on her lap and stroked it. She felt a tingling in her hands and arms, but that came from walking, she supposed. And when she breathed, something light and sad - no, not sad, exactly — something gentle seemed to move in her bosom.

Главная героиня рассказа - пожилая женщина, Мисс Брилл, которая в очередное воскресенье собирается в парк. Мисс Брилл очень взволнована в предвкушении прогулки, к которой она тщательно готовится. Описание её эмоционального состояния представлено НПР, характеризующейся высокой степенью эмотивности, которая создаётся конвергенцией таких стилистических приёмов, как восклицательные предложения (Dear little thing!; Little rogue!; Oh, how sweet it was to see them snap at her again from the red eiderdown! ), метафора (the blue sky powdered with gold); эпитет (brilliantly fine); сравнение (great spots of light like white wine splashed over, a faint chill, like a chill from a glass of iced water before you sip), параллельные конструкции (She had taken it out of its box that afternoon, shaken out the moth powder, given it a good brush, and rubbed the life back into the dim little eyes), повторы (Little rogue; sad).

Следующий отрывок демонстрирует роль НПР в создании образности.

Oh dear, how hard it was to be indifferent like the others! She tried not to smile too much; she tried not to care. But every single thing was so new and exciting ... Meg's tuberoses, Jose's long loop of amber, Laura's little dark head, pushing above her white fur like a flower through snow. She would remember for ever. It even gave her a pang to see her cousin Laurie throw away the wisps of tissue paper he pulled from the fastenings of his new gloves. She would like to have 
kept those wisps as a keepsake, as a remembrance. Laurie leaned forward and put his hand on Laura's knee (Mansfield, Her First Ball).

В отрывке даётся описание бала, который для героини рассказа является первым в жизни. Используемая В НПР конвергенция, включающая олицетворения (it couldn't wait; it was dancing already; it leaped almost to the ceiling; music that came flying; came a burst of tuning; flags ... were talking), восклицательное предложения (Oh dear, how hard it was to be indifferent like the others!), метонимии (strange faces smiled; strange voices answered), параллельные конструкции (dark girls, fair girls), перечисления (patting their hair, tying ribbons again, tucking handkerchiefs down the fronts of their bodices, smoothing marble-white gloves; Meg's tuberoses, Jose's long loop of amber, Laura's little dark head), сравнение (like a flower through snow; like a flower that is tossed into a pool), параллельные конструкции (a tall, fair man; a dark man; then quite an old man; then cousin Laurie...and Laura; she tried not to smile...she tried not to care), повтор (she tried, their), способствует наглядно-образному воспроизведению и изображению бала, при этом создаются образы участников, дается описание их движений, одежды. Дискурсивная личность персонажа в данном случае проявляется в выражении его эмоционального состояния: восхищения, волнения, ожидания чего-то нового.

Особенностью стилистической маркированности НПР является также её стилистическая гетерогенность, проявляемая в использовании в составе НПР лексики, принадлежащей различным стилистическим пластам. Рассмотрим данное явление на примере следующей НПР:

Suddenly - dreadfully - she wakes up. What has happened? Something dreadful has happened. No - nothing has happened. It is only the wind shaking the house, rattling the windows, banging a piece of iron on the roof and making her bed tremble. Leaves flutter past the window, up and away; down in the avenue a whole newspaper wags in the air like a lost kite and falls, spiked on a pine tree It is cold. Summer is over - it is autumn - everything is ugly. The carts rattle by, swinging from side to side two Chinamen lollop along under their wooden yokes with the straining vegetable baskets - their pigtails and blue blouses fly out in the wind. A white dog on three legs yelps past the gate. It is all over. 'What is? Oh, everything! (Mansfield K.).

Авторский план представлен языковыми единицами книжной лексики, о чем свидетельствует использование многочисленных образных выражений, описывающих внутреннее состояние персонажа (Leaves flutter past the window; down in the avenue a whole newspaper wags in the air like a lost kite and falls, spiked on a pine tree). Лексический состав речи персонажа в НПР максимально приближен к диалогу и разговорной речи. Используются обрывистые и фрагментарные синтаксические конструкции, свойственные разговорной речи: вопросительные и восклицательные предложения (What has happened?; What is?; Oh, everything!), отрицательные предложения, выражающие сомнение (No - nothing has happened), инверсия (Suddenly - dreadfully - she wakes up; Summer is over - it is autumn - everything is ugly), междометия $(\mathrm{Oh})$, что в целом служит прямому восприятию читателем речи 
персонажа и способствует проникновению в его мысли и переживания. Кроме того, эмотивность подтверждается использованием эмотивно маркированных лексем (dreadful, bad, rattling the windows, lost kite, pigtails), передающих внутреннее состояние персонажа и способствующих выражению его дискурсивной личности.

Таким образом, НПР, являясь сложным стилистическим приемом, выступает в качестве одного из средств выражения дискурсивной личности автора и персонажа, характеризуется двуплановостью, проявляемой в корреляции авторской речи и речи персонажа, стилистической маркированностью создаваемых в конвергенции стилистических средств, гетерогенностью, обусловленной смешением литературнокнижного и разговорного стилей, а также спецификой, направленной на выражение национально-культурных особенностей.

\section{Использованная литература}

1. Арнольд И.В. Стилистика. Современный английский язык: Учебник для вузов. 5-е изд., испр. и доп. М.: Флинта: Наука, 2002. 384 с.

2. Ашурова Д.У. Производное слово в свете коммуникативной теории языка. - Ташкент: Фан, 1991. - 100 c.

3. Гальперин И.Р. Текст как объект лингвистического исследования - М.: Наука, 1981. -139 с.

4. Кухаренко В.А. Интерпретация художественного текста. - М.: Просвещение, 1988. - 192 с.

5. Словарь литературоведческих терминов, / Редакторысоставители Л.И. Тимофеев и С.В. Тураев. - M., 1974. — URL: http://niv.ru/doc/dictionary/literary-terminology/index.htm

6. Словарь лингвистических терминов. Жеребило Т. В. Назрань: Пилигрим, 2010. - 486 с.

7. Философский энциклопедический словарь. - M.: Советская энциклопедия. Гл. редакция: Л. Ф. Ильичёв, П. Н. Федосеев, С. М. Ковалёв, В. Г. Панов. 1983. - 889 с.

8. Серебренников Б.А. Как происходит отражение картины мира в языке/ Роль человеческого фактора в языке: язык и картина мира. - М.: Наука, 1988. - С. 87-108 с.

9. Серикова Л.В. Портрет персонажа в прозе В.М. Шукшина: системное лексико-семантическое моделирование. Автореф. дис...канд. филол. наук. - Бийск: 2004. - 24 с.

10.Хализев В.Е. Теория литературы. - М.: Азбуковник, 1999. - 403 с.

11. Collection of English classical literature. 100 Selected Stories. — Wordsworth Editions Limited, 1995. — 735 p.

12. English Selected prose. — М.: Менеджер, 1999. — 588 р.

\section{References}

1. Arnol'd I.V. Stilistika. Sovremennyj anglijskij yazyk (Stylsitics, modern English language) Uchebnik dlya vuzov. 5-e izd., ispr. i dop. M.: Flinta: Nauka, 2002. 384 s. 
2.Ashurova D.U. Proizvodnoe slovo v svete kommunikativnoj teorii jazyka (Derived Word in the Light of Communicative Theory of the Language), Tashkent, Fan, 1991, 100 p.

2. Gal'perin I.R. Tekst kak obekt lingvisticheskogo issledovanija (Text as an object of investigation) Moscow, Nauka, 1981, 139 p.

Kuharenko V.A. Interpretacija hudozhestvennogo teksta (Interpretation of Literary Text), Moscow: Prosveshhenie, 1988, 192 p.

3. Slovar' literaturovedcheskih terminov (Dictionary of Literary Terms), Moscow, 1974, available at: http://niv.ru/doc/dictionary/literary-terminology/index.htm

4. Slovar' lingvisticheskih terminov (Dictionary of Linguistic Terms), Zherebilo T. V., Nazran', Piligrim, 2010, 486 p.

5. Filosofskij jenciklopedicheskij slovar (Dictionary of Philosophical Terms), Moscow, Sovetskaja jenciklopedija, 1983, 889 p.

7. Serebrennikov B.A. Rol' chelovecheskogo faktora v jazyke: jazyk i kartina mira (Explication of Picture of the World in the Language), Moscow: Nauka, 1988, pp. 87-108.

8. Serikova L.V. Portret personazha v proze V.M. Shukshina: sistemnoe leksiko-semanticheskoe modelirovanie (Portrait of Personage V.M. Shukshin, Systematic Lexic-Semantic Modelling), extended abstract of candidate's thesis, Bijsk, 2004, 24 p.

9. Halizev V.E. Teorija literatury (Theory of Literature), Moscow, Azbukovnik, 1999, 403 p.

10. Collection of English classical literature. 100 Selected Stories, Wordsworth Editions Limited, 1995, 735 p.

11. English Selected prose, Moscow, Menedzher, 1999, 588 p. 